overseas on anything like this scale. The idea is, however, so attractive that it is bound to be taken up increasingly by the wealthy private universities. That should console those with ruinously expensive stately homes on their hands.

\section{DATA TRANSMISSION Good News for Data Mongers}

Anxious to redeem its battered image with at least one section of its public, the British Post Office last week announced new measures which everyone hopes will do something to encourage the widespread use of computers in Britain. Recently the Post Office has shown signs of becoming aware of the need for some kind of national data transmission network, and the new measures should go some way to cater for the present demand and also to provide a basis for anticipating future needs. In essence, the facilities announced by the Post Office include what it calls the Midnight Line-a way of encouraging the transmission of data over the telephone by night when the system has ample spare capacity - and a switched data transmission network between London, Birmingham and Manchester. Mr John Stonehouse, the Postmaster General, must also have been glad last week to announce modest reductions in the hire charge for the terminal units-called "modems". From April 1, 1969, rentals will be reduced by between 5 and 16 per cent to $£ 100$ per modem-year.

For a fixed annual charge, customers of the Midnight Line will be able to make any number of dialled calls within Britain between midnight and 6 a.m. According to the Post Office, the Midnight Line will be economically attractive to customers making telephone calls which last about two hours a day over distances of more than 35 miles, and will be equally suitable for data or speech, although it seems quite clear that the objective of the new service, due to function by next April, is to foster data transmission traffic. The question will no doubt arise whether the staffs of computing departments are more inclined than the general public to make use of the telephone system between midnight and 6 a.m. The Post Office would argue that computers can be programmed in advance to transmit data at any time, but computer operators may be unwilling to leave precious data in the hands of remotely operated machines. The use of the public telephone system for this new development would in any case seem to limit the speeds at which data can be transmitted.

Another development announced last week in what seems to have been a package designed to please was the setting-up of a high-speed switched data network linking London, Birmingham and Manchester. This is expected to be ready late in 1969 and will transmit data at 48 kilobits per second. The hope is that the network will eventually spread and become the kernel of a national data transmission system. To find out what shape the network of the future should take, the Post Office is paying for two studies, one by Standard Telecommunications Laboratories Ltd and the other by British Telecommunications Research Ltd, which should lead to a plan for a national network by the spring of 1970. The Post Office has also commissioned a study by International Computers Ltd of the way in which a data network would be used and a market survey of the demands for data transmission services over the next 15 years.

This may be a start, but it is likely to be a long time yet before the British Post Office emulates the recent decision in the United States that the American Telephone and Telegraph Co. will in future allow equipment it does not own to be connected to its telephone lines. In the past, telephone companies have stuck quite rigidly to the rule that devices over which they have no control should not be connected to the system because of the havoc they might cause. With the advent of data transmission over telephone lines, the ruling has recently been under serious pressure, but it has nevertheless come as a surprise that AT \& T should have responded as freely as it has done to a recent decision by the Federal Communications Commission that the restrictions were unlawful. Under new regulations, which are expected to become valid by November 1, it will be possible to attach private equipment to the telephone system through a device rented from the company at $\$ 2$ a month which incorporates fuses and a telephone dial. Questions about attachments to the telephone network are likely to continue, however, chiefly because the new regulations seem to be sufficiently ambiguous to make it unclear exactly what attachments the American Telephone and Telegraph Co. will tolerate. It seems certain, for instance, that the company will stand out against the connexion of private communication networks to the telephone system.

\section{FLOOD PROTECTION When London Floods}

Professor H. Bondi's lucid report on the feasibility of a London flood barrier, which was instigated by the Ministry of Housing and Local Government after much prodding from the London County Council and the Greater London Council, and published last February (Nature, 21\%, 800; 1968), urged the construction of a movable barrier across the Thames to eliminate the risk of a major flood. In the present economic climate, it is

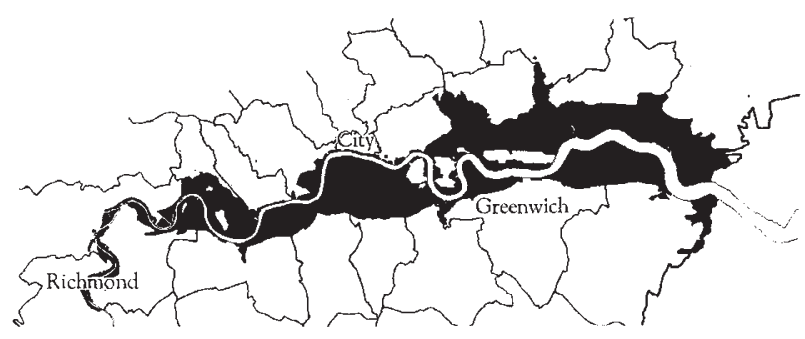

The area in central London that lies below the existing river defence and might be flooded if the Thames rose much more than 17 feet above sea level.

surely wishful thinking to believe that such grand schemes-let alone the Channel dam-will get beyond the drawing board. The project has not, however, been completely shelved. The Greater London Council, with the approval of the Ministry and in consultation with the Port of London Authority, has gone ahead with investigations of the Bondi proposals and some of its own. A $600 \mathrm{ft}$ model of the Thames from Teddington to Southend is under construction at the Hydraulic Research Station at Wallingford, and the data from a 